\title{
Agricultural productivity under taungya and non-taungya land-use options: a case study of Vandeikya Local Government area, Benue State, Nigeria
}

\author{
Adebola O. ADEGEYE, Saka Oladunni JIMOH* and Stephen Iorliam AGERA \\ Department of Forest Resources Management, University of Ibadan, Ibadan, Nigeria. \\ ${ }^{*}$ Corresponding author, E-mail: jimohsaka@yahoo.com; Tel: +234-8035028242
}

\begin{abstract}
Taungya farming is a special arrangement between the forestry department and farmers, which combines the production of both arable and forest tree crops simultaneously on a piece of land. The practice was adopted in Vandeikya Local Government area of Benue State Nigeria, in mid 1950s up to 2000. This study evaluated the method as an option for food and fiber production compared to the traditional farming and forest management practices. Using Stratified random sampling, two sets of questionnaire were used to appraise the productivity of some arable crops and forest regeneration under taungya and non-taungya cultural practices. The yields of arable crops were significantly higher under taungya farming that in non-taungya plots in the study area. There was however no significant difference in the total forest area regenerated under the two landuse systems. The apparent land hunger among farmers is a favourable factor for adoption of taungya as a land use option in the study area. There is need to adopt multi-species planting approach in future programmes. Also, the land tenure system which limits access to land by strangers needs to be reviewed and greater awareness on the programme needs to be generated among the farmers and forestry staff alike.

(C) 2011 International Formulae Group. All rights reserved.
\end{abstract}

Keywords: Taungya, agroforestry, arable crop, productivity, forest.

\section{INTRODUCTION}

The biggest challenge for sustainable development in many parts of Africa, appears to be how to provide enough suitable land to poor farmers while preserving a safe environment and conserving biodiversity (Sadio and Daga, 2004). Management options for optimizing productivity in plant communities under taungya practice are based on the manipulation of solar radiation profile. The principle of plant productivity has been viewed as a system of conversion of solar energy into chemical energy that can be transported and stored through the process of photosynthesis (World Agrofrestry Center,
2008). The selection of species, their arrangement and maintenance determine the photosynthetic efficiency of the whole plant community.

The traditional bush fallow system could be sustained with sufficient fallow length which allows the soil to replenish itself during the fallow period. Furthermore, biodiversity in shifting cultivation landscapes is of interest because it contributes to agricultural sustainability and human wellbeing, and may also contribute to the conservation of native forest biodiversity (Bryan and Robert, 2004). 
However, increase in human population leads to decrease in length of fallow and increase in cropping intensity. Shortened fallows caused by population explosion and excessive demand for farmland in many parts of Nigeria and elsewhere in Africa has led to over-cropping of available land with various environmental consequences which include: degradation of rain-fed crop lands, fuel wood and fodder shortages, sheet and gully erosion (Okojie, 1997; Sadio and Daga, 2006). This in turn decreases soil fertility and productivity and keeps agricultural productivity at a marginal level.

Sanchez (1997) observed that high cost of fertilizer has compounded the problem of decreasing soil fertility and the accompanying declining crop productivity as most farmers cannot afford to buy fertilizers at high costs. Soil management practices should at this time be concerned with farming systems aimed at optimizing and sustaining productivity. Taungya farming as an aspect of agro-forestry has the potential of meeting these criteria. Bashir et al. (2006) affirmed that species mixtures instead of plantation monocultures should be used in order to improve regional biodiversity and maintain ecosystem resilience.

Higher crop yields have been observed when agricultural crops are planted near leguminous trees such as Faidherbia (Acacia albida) (Del.) Chev (Kumar, 2006). The choice of trees and crops for inclusion in proposed taungya plantations should however take cognizance of the various intra and interspecific interactions. It is thus the objective of this study to compare the yield of agricultural crops in taungya farming practice with nontaungya farming practice and to compare the success of forest plantation establishment under the two systems in Vandeikya Local Government Area, Benue State, Nigeria.

\section{MATERIALS AND METHODS}

\section{Study area}

Vandeikya Local Government Area (VLGA) is located between longitude $8^{0} 45^{\prime}-$ $9^{0} .00 \mathrm{E}$ and longitude $6^{0} 30^{\prime}-7^{0 .} 00^{\prime} \mathrm{N}$. VLGA is made up of twelve administrative wards
(Figure 1). The projected population of the study area is about 532,881 (www.benuestate.gov.ng May 2, 2010).

There are two seasons namely dry and wet seasons which occur from November to March and April to October respectively. The climate is the tropical humid type with very high temperatures between March and April. The cool, dry harmattan weather is witnessed between December and February. The terrain is undulating, low-lying and drained mainly by Rivers Aya, Sambe, Be and Uaghshu.

The Local Government Area has 48 forest estates unequally dispersed in the 12 wards. Most of these forest estates were established with the assistance of the host or neighbouring communities through taungya system between 1945 and 1970 and were inherited from the defunct Gboko Division (formerly in Tiv Native Authority). For administrative convenience, the forest estates in each ward are grouped into a single management plan. This study is based on taungya operations within the forest estates owned by the local government council and does not include privately owned forest estates.

\section{Data collection}

Primary data were obtained using structured questionnaires while the secondary data were obtained from the records of the Department of Agriculture of VLGA. The twelve wards in VLGA were listed in alphabetical order and all the six oddnumbered wards were selected through balloting. The six wards surveyed included: Mbadede, Mbagbera, Mbaityough Mbakaage, Ningev and Tsambe (Figure 1).

The two sets of questionnaire administered included: 200 for taungya farmers on VLGA forest estates and 16 for government officials working in VLGA forestry service. The universal population of the farmers was 562, while the corresponding population of forestry staff was 16 . This constitutes approximately $36 \%$ sampling intensity for taungya farmers and $100 \%$ for forestry officials. 


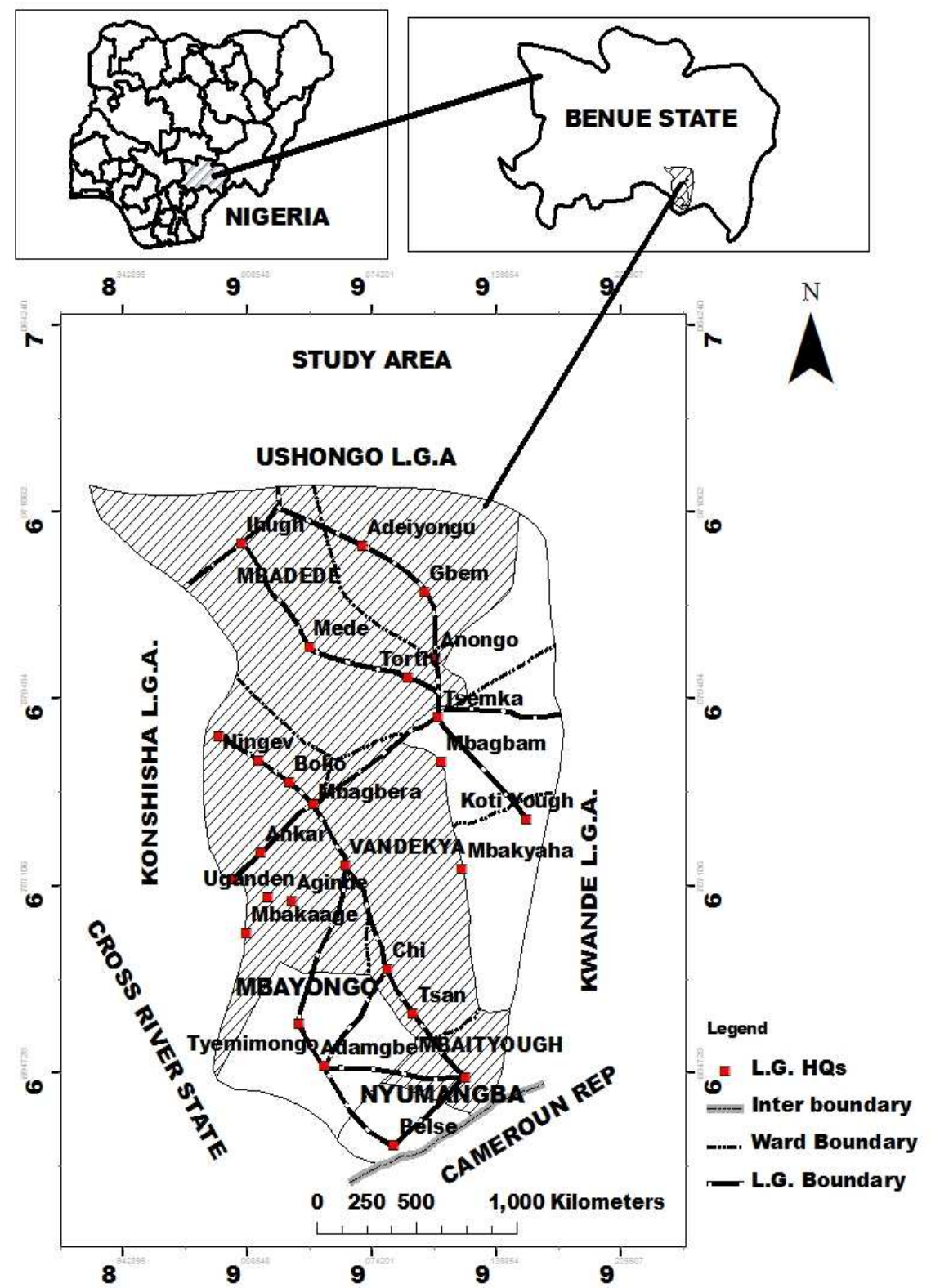

Figure 1: Map of Vandeikya Local Government area showing survey wards. Source: Department of Agriculture, Vandeikya Local Government Secretariat, Benue State, Nigeria. 
The questionnaires sought information on the productivity of agricultural crops grown under taungya and non-taungya plots as well as the forest areas regenerated through taungya farming and non-taungya plantation establishment techniques. Through personal interviews, all the 216 questionnaires administered were retrieved. Edaphic and climatic properties between the various pairs of taungya and non-taungya plots were assumed to be fairly uniform enough to allow uniformity in crop productivity. Thus, any differences noticed in crop yields were ascribed to the cultural practices adopted.

\section{Data analysis}

Descriptive statistics, student's T-test and analysis of variance (ANOVA) were used for data analysis. Post-mortem analysis involving the use of Least Significant Difference (LSD) was also employed to validate any observed variation.

\section{RESULTS}

\section{Demographic attributes of respondents}

The forestry members of staff were aged between 31 and 50 years; $87.50 \%$ of them were married. Majority of the staff had low levels of educational attainment with $68.75 \%$ having primary and secondary education without professional training. Over sixty two percent of the forestry staff had annual incomes of between $\$ 111,000.00$ and $\$ 150,000.00 \quad$ ( $\#$ = Naira). Twenty seven percent of the farmer respondents were females. Sixty eight percent of them were aged between 31 and 50 years. Eighty six percent of the farmer respondents were married with family sizes of 7-12. Thirty eight percent of the farmers were literate and 55\% of them earned between $\$ 21,000.00$ and $\$ 40,000.00$ per annum.

\section{Comparison of crop productivity on taungya and non-taungya plots}

The mean yield per hectare of each of the crops for the six sampled wards is presented in Table 1. The mean yields of yam, cassava, rice, sweet potatoes, maize, groundnuts, soybeans, guinea corn, cow pea, pepper and melon were significantly higher on taungya plots than non-taungya plots. Crop yield ranged from $306.67 \mathrm{~kg} / \mathrm{ha}$ to $1,698.33$ $\mathrm{kg} / \mathrm{ha}$. At $\mathrm{P}=0.05$, $\mathrm{t}$-values ranged from 1.80 to 9.82 at degree of freedom ' 10 '. The result of $t-$ test analysis presented in Table 1 indicates significant difference in crop yield on taungya non-taungya plots $(\mathrm{P}=0.05)$. We therefore conclude that there were significantly higher yields on taungya plots than non-taungya plots in the study area provided that edaphic characteristics are sufficiently uniform to support fairly uniform crop productivities.

\section{Forest area regenerated through taungya and non-taungya systems}

The forest areas regenerated through taungya and non-taungya systems between 1955 and 2000 (for sampled years only) are as indicated in Table 2. A total of 63 hectares were regenerated through taungya, while a total of 74.7hectares were regenerated through other means (Non-taungya). The mean forest areas regenerated through taungya and nontaungya practices between 1950 and 2000 were 6.30 and 7.47 Ha per year respectively .These areas did not differ significantly $(\mathrm{P}=$ $0.05)$.

The reforestation efforts of VLG were centred on re-stocking with Gmelina arborea (Roxb), Tectona grandis (Linn. F) as well as Faidherbia species. The modal class of 41-60 and accounted for $46 \%$ of the farmers. The class 61-80 had the least respondents (7\%).

ANOVA computation in Table 3 indicates that there were no significant differences in the number of trees planted among the six sampled wards $(\mathrm{P}>0.05)$.

Reforestation outside forest estates of VLGA was low with only $6 \%$ of the farmers planting tree seedlings on both government forest estates and their own lands. $62.5 \%$ of the farmers were willing to practice taungya outside government forest estates but had no personal land while $31.5 \%$ of the farmers were not favourably disposed to practicing taungya on their own lands. Land tenure and availability were identified as the major obstacles to taungya practice. 
Table 1: T-test of differences between mean crop yields per/ha for taungya and non-taungya plots.

\begin{tabular}{|c|c|c|c|c|c|}
\hline Parameter & \multicolumn{2}{|l|}{ Mean yield } & t-tab & Df & $\mathbf{P}$ \\
\hline \multicolumn{6}{|l|}{ Yam (Dried chips) } \\
\hline Taungya & 1223.33 & $2.45^{*}$ & 0.26 & 10 & 0.0342 \\
\hline Non-taungya & 1075.00 & & & & \\
\hline \multicolumn{6}{|c|}{ Cassava (Dried Chips) } \\
\hline Taungya & 1698.33 & $9.83 *$ & 0.26 & 10 & 0.0000 \\
\hline Non-taungya & 1372.67 & & & & \\
\hline \multicolumn{6}{|l|}{ Rice (unmilled) } \\
\hline Taungya & 1155.00 & $7.05 *$ & 0.26 & 10 & 0.0000 \\
\hline Non-taungya & 833.33 & & & & \\
\hline \multicolumn{6}{|c|}{ Sweet Potatoes (Dried Chips) } \\
\hline Taungya & 1471.67 & $7.70 *$ & 0.26 & 10 & 0.0000 \\
\hline Non-taungya & 923.33 & & & & \\
\hline \multicolumn{6}{|l|}{ Maize } \\
\hline Taungya & 1133.33 & $13.40^{*}$ & 0.26 & 10 & 0.0000 \\
\hline Non-taungya & 710.00 & & & & \\
\hline \multicolumn{6}{|c|}{ Groundnuts (unshelled) } \\
\hline Taungya & 1083.33 & $6.14 *$ & 0.26 & 10 & 0.0001 \\
\hline Non-taungya & 756.67 & & & & \\
\hline \multicolumn{6}{|l|}{ Soybeans } \\
\hline Taungya & 620.00 & $5.18 *$ & 0.26 & 10 & 0.0004 \\
\hline Non-taungya & 408.33 & & & & \\
\hline \multicolumn{6}{|l|}{ Guinea corn } \\
\hline Taungya & 725.00 & $5.73 *$ & 0.26 & 10 & 0.0001 \\
\hline Non-taungya & 516.67 & & & & \\
\hline \multicolumn{6}{|l|}{ Beans } \\
\hline Taungya & 458.33 & $2.42 *$ & 0.26 & 10 & 0.0358 \\
\hline Non-taungya & 408.33 & & & & \\
\hline \multicolumn{6}{|l|}{ Pepper } \\
\hline Taungya & 366.67 & $1.80^{*}$ & 0.26 & 10 & 0.1018 \\
\hline Non-taungya & 320.00 & & & & \\
\hline \multicolumn{6}{|l|}{ Melon } \\
\hline Taungya & 306.67 & 2.07 & 0.26 & 10 & 0.0655 \\
\hline Non-taungya & 250.00 & & & & \\
\hline
\end{tabular}


Table 2: Forest regeneration through Taungya and non-taungya methods.

\begin{tabular}{llll}
\hline \multicolumn{4}{l}{ Forest Land Area Regenerated (Ha) } \\
\hline Year & Taungya & $\begin{array}{l}\text { Other Methods } \\
\text { (Non-taungya) }\end{array}$ & Total \\
\hline 1955 & 3.0 & 1.0 & 4.00 \\
1960 & 2.3 & 4.5 & 6.80 \\
1965 & 6.0 & 7.5 & 13.50 \\
1970 & 9.0 & 11.0 & 20.00 \\
1975 & 9.0 & 7.9 & 16.90 \\
1980 & 9.9 & 6.2 & 16.10 \\
1985 & 3.2 & 9.1 & 12.30 \\
1990 & 10.0 & 8.7 & 18.70 \\
1995 & 5.6 & 7.1 & 12.70 \\
2000 & 5.0 & 11.7 & 16.70 \\
Total & 63.0 & 74.7 & 137.70 \\
Means & 6.3 & 7.47 & 13.77 \\
\hline Source: Department of Agriculture Vandeikya LGA.
\end{tabular}

Source: Department of Agriculture Vandeikya LGA.

Table 3: Analysis of variance table for tree seedlings planted among the six wards.

\begin{tabular}{lllllll}
\hline Source & DF & SS & MS & F & F-Tab & Remarks \\
\hline Ward & 5 & 641 & 128 & 0.27 & 3.02 & $\mathrm{~ns}$ \\
Error & 194 & 93398 & 481 & & & \\
Total & 199 & 94039 & & & & \\
\hline P> 0.05, ns: not significant & & & &
\end{tabular}

\section{DISCUSSION}

The higher crop yields observed on taungya plots could be attributed to better soil conditions in the forest reserves where the crops were raised. Undoubtedly, organic matter accumulation from decomposed litters and reduced leaching and erosion in the forest environment could contribute to greater soil productivity under the forest ecosystem. Fallows, incorporation of green manure, fodder and planting of grain legumes are known to have an overall effect on increasing the soil organic matter, nutrient cycling, soil fertility, soil fauna, weed and pest control, as well as fuel wood production (Ogungbile and Manyong, 1998; Bashir et al., 2006). Intercropping of agricultural crops among the tree seedlings can increase crop productivity through positive interactions among the intercropped species. The findings of the current study agrees with the observation of
Anderson and Swift (1993) that plant litters high in nutrients (especially nitrogen) and which decompose rapidly increased crop productivity. In a similar study in Kenya, Bohringer and Akinifesi (2001) reported a maize yield of about $4.1 \mathrm{t} / \mathrm{ha}$ in agroforestry system compared to $1.7 \mathrm{t} / \mathrm{ha}$ in non-fertilized soils continuously planted to maize.

The low literacy rate among the farmers and low educational attainment of forestry service staff could slow down the adoption rate of taungya as a food production technology in the study area. Over $60 \%$ of the farmers had no personal land on which to practice taungya and had to rely on government estates to secure land for taungya practice. Joyce (1992) observed that the level of adoption of taungya practice may be low initially, but as population pressure on land increases, it would improve considerably over 
time. This is a favourable factor for the adoption of taungya in this area.

Socio-cultural considerations if not taken seriously prior to the inception of taungya programmes could hinder the success of the programme.

Ecologists place a lot of premium on multi-species forest plantations compared to monoculture stands. The fact that forest regeneration programmes in this area are largely through mono-specific plantations establishment is a major ecological drawback for the programme (Taylor, 1999). Seventy six percent of the farmer respondents recalled existence of exotic monoculture stands on their allocated plots before such plots were cleared for taungya. This has serious ecological implications particularly as regards to biodiversity conservation and ecological and economic vulnerability of the dependent communities. (Mohan et al., 2006; Lindara et al., 2006.) The local communities and the forestry department need to be sensitised on the benefits of multi-species plantations as well as the benefits and demerits of sustainable taungya practice. There is need to develop appropriate management techniques for compatibility of the woody perennials and the arable crops; as there may also be negative interactions in certain herbaceous crop mixtures (Kumar, 2006).

The manual nature of taungya requires large households that can share labour for agricultural production for expanded operation. Households capable of supplying farm labour are most likely to participate more meaningfully in taungya since there would be division of labour. The low participation of women in taungya farming could be attributed to the inability of women to pay for the initial high labour cost for land clearing.

\section{Conclusion}

An assessment of the productivities of some agricultural crops on taungya and nontaungya plots indicates that generally, farming on taungya plots is more productive than farming on non taungya plots. In VLGA, there are no significant differences in forest areas in respect of reforestation through taungya and non-taungya methods. An overwhelming majority $(68.5 \%)$ of the farmers had no personal land on which to practice taungya farming. Reforestation efforts were tilted in favour of mono-species plantations without regard for ecological sustainability and species diversity expected of sustainable taungya practice.

Taungya farming is desirable in the study area as a means of forest regeneration and food production. It should be intensified and refined for better adoption by farmers. Land tenure laws have to be reviewed to give taungya farmers easy access to land. There is also need to recruit qualified forestry extension workers to provide necessary technical assistance to farmers for increased adoption of taungya practice.

\section{REFERENCES}

Anderson LS, Swift MJ. 1993. Decomposition in the Tropical Forest. In Tropical Rain Forest: Ecology and Management, Whitmore SI, Chadwick AC (eds) Blackwell: Oxford, U.K.; 287-309.

Bashir J, Eyasu EKM. 2006. Role of Agrofrestry in improving food Security and Natural Resource Management in drylands: a Regional Overview. Journal of Drylands, 1(2):206-211

Bohringer A, Akinnifesi F. 2001. Facilitating $\mathrm{g}$ the wider use of agroforestry for development in Southern Africa In Development and Agroforestry: Scaling up the Impacts of Research. The way Ahead for the Domestication and Use of Indigenous Fruit Trees, Franzel et.al. (Eds.)

Bryan F, Robert N. 2004. The Contribution of Shifting Cultivation Landscapes to the Conservation of Tropical Biodiversity: A Forest Ecologist's Viewpoint. P71. In Working Together for Sustainable Land Use Systems. Book of Abstracts, $1^{\text {st }}$ World Congress of Agroforestry. 27 June-2 July 2004, Orlando, Florida, USA, 488P. 
Joyce AS. 1992. Diffusion and Adoption. $2^{\text {nd }}$ IRNR/AFNETA Agroforestry / Alley Farming for Development Training Course, Kumasi, Ghana, 10-21 August, 1992.

Kumar BM. 2006. Agroforestry: the new old paradigm for Asian food security. Journal of Tropical Agriculture, 44(1-2): 1-14.

Lindara LMJK, Johnsen FH, Gumatilake HM. 2006. Technical Efficiency in the species based agroforestry sector in Matale District, Sri Lanka. Agroforestry System, 68: 221-223.

Mohan S, Alavalapati JRR, Nair PKR. 2006. Financial Analysis of Home Gardens: A Time Tested Example of Sustainable Agroforestry, Kumar BM, Nair PKR (eds). Springer Science: Dordrcht: 283296.

Nair K 1993. An Introduction to Agroforestry. Kluver Academic Publishers; 499.

Ogungbile AO, Manyong VM. 1998. Economics of maintaining and enhancing natural resources base through the adoption of stabilized short fallow systems. In Strategies for Farming
Systems. Development in Sub-Saharan Africa. Atayi EA, Ladipo DO (eds). IITA: Ibadan.

Okojie JA. 1997. Forestry and the Environment. Paper Presented at the Department of Forestry, University of Ibadan. Symposium, 10 ${ }^{\text {th }}$ July, 1997.

Sadio S, Dagar JC. 2004. Agroforestry and Food Security in Africa P.68 In Working Together for Sustainable Land Use Systems 27 June - 2 July 2004, Book of Abstracts $1^{\text {st }}$ World Congress of Agroforestry,Orlando: Florida, USA 488.

Sanchez PA. 1997. Soil productivity and sustainability in agroforestry systems. In Agroforestry: A Decade of Development. ICRAF: Nairobi.

Taylor DH. 1999. Requisites of Thriving Rural Non-rural Forest Products Enterprises. Unasylva; 198/50; 3-8.

www.benuestate.gov.ng May2, 2010.

World Agroforestry Center 2008. Agroforestry for food security and healthy ecosystems. Annual Report of the World Agroforestry Center. Nairobi, Kenya, 2007-2008: 68. 